\title{
Pengelolaan Keuangan Pribadi Bagi Siswa Siswi SMA Badan Pendidikan Kristen Penabur Cirebon di Masa Pandemi
}

\author{
Diana Frederica $^{1}$, Subagyo $^{2}$, Eka Desy Purnama ${ }^{3}$, Deni Iskandar ${ }^{4}$ \\ ${ }^{1,2,4}$ Program Studi Akuntansi, Fakultas Ekonomi dan Bisnis, Universitas Kristen Krida Wacana \\ ${ }^{3}$ Program Studi Manajemen, Fakultas Ekonomi dan Bisnis, Universitas Kristen Krida Wacana \\ Email: diana.frederica@ukrida.ac.id
}

\begin{abstract}
Abstrak - Pada masa pandemi covid 19, penghasilan keluarga relatif menurun. Namun, biaya hidup relatif sama, bahkan meningkat untuk kebutuhan pembiayaan kesehatan. Usia muda, yakni siswa/i pada masa sekolah, memiliki gaya hidup yang perlu dikelola terutama dalam mempergunakan uang. Tujuan dari pengabdian kepada masyarakat ini adalah memberikan pembekalan siswa/i Sekolah Menengah Atas Badan Pendidikan Kristen Penabur Cirebon tentang pengelolaan keuangan di masa pandemi agar kebutuhan hidup tercukupi; dosen Fakultas Ekonomi dan Bisnis Universitas Kristen Krida Wacana dapat mengaplikasikan ilmu yang dimiliki kepada masyarakat, khususnya kepada siswa/i; serta merupakan sarana pelatihan dan pendidikan non formal bagi mahasiswa Fakulas Ekonomi dan Bisnis melalui berinteraksi dengan masyarakat secara langsung. Ruang lingkup kegiatan ini adalah penyuluhan tentang siklus keuangan pribadi, perencanaan dan tips mengatur keuangan, pencatatan keuangan, dan pengenalan penggunaan kalkulator finansial. Metode kegiatan yang digunakan adalah penyuluhan, diskusi bersama, dan tanya jawab, serta pemberian umpan balik di akhir acara. Hasil dari kegiatan ini adalah menambah pengetahuan dan wawasan siswa/i tentang pengelolaan keuangan di masa pandemi; dosen dan mahasiswa Fakultas Ekonomi dan Bisnis dapat mengaplikasikan ilmunya kepada masyarakat. Peserta antusias dan bertanya tentang halhal penggunaan uang dalam kehidupan sehari-hari mereka. Melalui kegiatan ini, siswa/i diajak untuk mulai membedakan antara kebutuhan dan keinginan serta mengelola keuangan dengan baik, sehingga kebutuhan hidup dapat tercukupi dan memiliki tabungan atau investasi sejak dini.
\end{abstract}

Kata kunci - pengelolaan keuangan, siklus keuangan, pencatatan keuangan

Abstract-During the covid-19 pandemic, family income has decreased relatively. However, the cost of living is relatively the same, even increasing for health financing needs. Young people, namely students at school, have a lifestyle that needs to be managed, especially in using money. The purpose of this community service is to provide briefing for high school students from the Cirebon Penabur Christian Education Board regarding financial management during the pandemic so that their needs are fulfilled; lecturers of the Faculty of Economics and Business, Krida Wacana Christian University can apply their knowledge to the community, especially to students; as well as a means of training and non-formal education for students of the Faculty of Economics and Business through interacting with the community directly. The scope of this activity is counseling about personal finance cycles, financial planning and tips, financial records, and an introduction to the use of financial calculators. The method of activity used is counseling, joint discussion, and question and answer, as well as providing feedback at the end of the event. The results of this activity are to increase students' knowledge and insight about financial management during the pandemic; lecturers and students of the Faculty of Economics and Business can apply their knowledge to the community. Participants were enthusiastic and asked about things to use money in their daily lives. Through this activity, students are invited to begin to distinguish between needs and wants and to manage finances well, so that the necessities of life can be fulfilled and have savings or investments from an early age. 
Keywords-financial management, financial cycle, financial records

\section{Pendahuluan}

Berbagai tantangan telah muncul akibat kehadiran pandemi covid 19 dan telah membawa perubahan terhadap dunia yang tidak pernah terbayangkan sebelumnya. Di Indonesia, upaya untuk menghambat penyebaran virus covid 19 telah menghambat kegiatan perekonomian dan dampaknya terhadap tingkat kesejahteraan sosial semakin dirasakan masyarakat. Tingkat kemiskinan sempat menurun beberapa tahun belakangan ini, namun tingkat kemiskinan kembali meningkat ketika pandemi covid 19. Satu dari 10 orang di Indonesia hari ini hidup di bawah garis kemiskinan nasional. Tingkat kemiskinan anak juga dapat meningkat secara signifikan.

Untuk mengukur dampak dari covid 19 terhadap rumah tangga Indonesia dan untuk memberikan informasi sebagai dasar pembuatan kebijakan pemerintah, UNICEF, UNDP, Prospera, dan The SMERU Research Insitute berkolaborasi dalam sebuah survei berskala nasional di akhir tahun 2020.

Survei ini meliputi 12.216 sampel rumah tangga representatif tingkat nasional yang tersebar di 34 provinsi yang dilakukan dalan kurun waktu antara Oktober dan November 2020. Dampak dari pandemi covid 19 akan terus dirasakan oleh berbagai lapisan masyarakat selama tahun 2021. Meskipun demikian, ketanggapan perlu diteruskan untuk meningkatkan kesejahteraan anak dan keluarga. Mitra pembangunan di Indonesia siap membantu dalam upaya ini [1].

Hasil survei Saiful Mujani Research Center (SMRC), yang dilakukan pada 18-20 Juni 2020 dengan sampel dipilih secara acak dari populasi pemilih yang berusia 17 tahun ke atas/sudah menikah sebanyak 1.978 responden, margin of error sebesar +/- 2,2\% dengan tingkat kepercayaan $95 \%$. Hasil survei menunjukkan kondisi ekonomi rumah tangga saat ini lebih buruk dari sebelum adanya Covid-19. Sebanyak $62 \%$ menjawab lebih buruk dan $9 \%$ jauh lebih buruk. Hanya $9 \%$ yang menyatakan merasa lebih baik. Sementara itu, terdapat $19 \%$ responden yang menilai tidak ada perubahan [2].

Walaupun merupakan masalah yang penting dan mendasar, bisa dikatakan bahwa hanya sebagian kecil saja masyarakat Indonesia yang memahami/memiliki pengetahuan keuangan secara memadai. Keputusan keuangan tentu saja akan memengaruhi kualitas hidup seseorang secara keseluruhan. Pada umumnya, sebagian besar dari masyarakat kita sering kali mengabaikan masalah perencanaan keuangan yang sangat penting ini. Hasilnya adalah bahwa tidak jarang pendapatan hanya mampir/ numpang lewat saja di rekening kita. Ketika kita menghasilkan sejumlah uang atau memperoleh pendapatan dari hasil pekerjaan kita, maka kita patut memahami benar ke mana saja setiap sen uang akan ditempatkan/dipergunakan.

Dalam keuangan, tujuan dibedakan menjadi tujuan jangka pendek dan tujuan jangka panjang. Tujuan jangka pendek (short-term goal) adalah tujuan keuangan yang ingin dicapai dalam waktu beberapa bulan atau tahun. Sementara itu, tujuan jangka panjang (long-term goal) merupakan tujuan keuangan yang ingin diwujudkan dalam waktu 10 tahun atau lebih [3].

Adapun tujuan keuangan jangka pendek bisa berupa: mengumpulkan dana darurat, membayar tagihan kartu kredit, mempersiapkan dana pernikahan, menabung untuk liburan, memperbaiki rumah, membeli gadget baru, memiliki proteksi dengan asuransi kesehatan dan asuransi jiwa dan lain sebagainya. Sedangkan tujuan keuangan jangka panjang bisa berupa: mempersiapkan dana pensiun, pendidikan anak, membayar KPR, mengumpulkan modal bisnis dan lain sebagainya [3].

Merencanakan keuangan jangka pendek atau jangka panjang dengan baik akan membantu individu dan keluarga dalam menciptakan pondasi keuangan yang kokoh dan stabil dalam setiap tahapan kehidupan.

Generasi muda yang merupakan bagian dalam keluarga, memiliki gaya hidup yang perlu dikelola, terutama dalam mempergunakan uang. Perencanaan keuangan yang dilakukan sejak dini akan membantu seseorang untuk merealisasikan tujuan hidupnya [4]. Kemudahan dan kemampuan dalam mengakses teknologi memudahkan kelompok usia muda dalam menerima informasi termasuk informasi terkait penawaran produk-produk/jasa-jasa. Penggunaan teknologi seperti internet memudahkan generasi muda untuk melakukan segala jenis transaksi, dari transportasi, membeli makanan, jalan-jalan, hingga berbelanja pakaian dan kebutuhan sehari-hari.

Pemanfaatan internet untuk transaksi membuat kalangan usia muda semakin terbiasa dengan budaya digital. Kemudahan yang ditawarkan dengan mengunakan berbagai platform membuat generasi muda cenderung konsumtif. Media digital berperan strategis dalam membentuk perilaku konsumtif melalui berbagai penawaran dan kemudahan layanan.

Kemudahan akses dalam berkonsumsi, membuat masyarakat terlebih generasi muda menjadi semakin konsumtif dan tidak rasional dalam menggunakan uang. Kemudahan akses tersebut membuat generasi muda sulit membedakan antara kebutuhan dan keinginan. Dengan pengelolaan keuangan yang benar, maka seseorang diharapkan bisa mendapatkan manfaat yang maksimal dari uang yang dimilikinya. Untuk mencapai kesejahteraan keuangan seseorang perlu memiliki pengetahuan, sikap, dan implementasi keuangan pribadi yang sehat. Kesejahteraan 
keuangan tidak hanya dinilai dari pendapatan yang didapat namun juga dari bagaimana pengelolaannya.

Perilaku seseorang dalam membelanjakan uangnya tergantung kepada pengetahuan keuangan yang dimilikinya. Kurangnya pengetahuan keuangan sejak dini dapat menyebabkan buruknya perilaku seseorang dalam melakukan pengelolaan keuangan pribadi seperti dalam hal merencanakan tabungan, investasi dan pola konsumsi. Untuk itu perlu adanya pengetahuan pengelolaan keuangan yang baik, agar seseorang dapat membuat pengelolaan keuangan mengenai pengeluaran keuangan yang dilakukan. Pemilihan pengelolaan keuangan yang buruk akan berdampak negatif dan akan berlanjut dalam jangka panjang. Untuk itu, perlu adanya perilaku manajemen keuangan yang baik untuk pengelolaan keuangan yang dimiliki.

Melakukan pengelolaan keuangan pribadi dengan baik dan benar bukanlah hal yang mudah untuk dilakukan. Hal ini harus melalui proses yang sebaiknya dilakukan sejak dini. Usia muda seperti siswa-siswi SMA terkadang mengalami defisit uang saku dibanding dengan yang seimbang dan surplus. Siswa-siswi cenderung menghabiskan uang untuk bersenang-senang daripada memenuhi kebutuhan penunjang untuk sekolah apalagi untuk investasi masa depan. Melatih dan memberikan pemahaman pengelolaan keuangan bagi siswa siswi SMA diharapkan dapat melatih mereka untuk dapat mengelola keuangan pribadi sehingga sejak dini dapat mengelola gaya hidup terutama dalam mengahadpi situasi ekonomi yang sulit di masa pandemic.

Faktor lain yang ikut mempengaruhi adalah peer pressure dari komunitas atau lingkaran pertemanan. Kaum muda akan merasa tertekan untuk ikut membeli barangbarang tertentu jika teman-teman di dalam komunitasnya juga menggunakan atau memiliki barang tersebut [5].

John Maynard Keynes pada tahun 1930 telah mengemukakan sebuah pendapat mengenai teori konsumsi. Teori konsumsi tersebut yaitu jumlah konsumsi saat ini berhubungan langsung dengan pendapatan. Dari kedua variabel tersebut dapat dijelaskan mengenai fungsi konsumsi yang menggambarkan tingkat konsumsi pada berbagai pendapatan [6]. Menurut pandangan Keynes besarnya konsumsi akan sangat bergantung dari besarnya pendapatan. Pada masa pandemi covid 19, rata-rata penghasilan keluarga relatif menurun. Namun, biaya hidup relatif sama, bahkan meningkat untuk kebutuhan pembiayaan kesehatan.

\section{LANDASAN TEORI}

\section{A. Perencanaan Keuangan}

Perencanaan Keuangan secara definisi menurut Certified Financial Planner, Board of Standards, Inc., adalah proses mencapai tujuan hidup seseorang melalui manajemen keuangan secara terencana. Tujuan hidup dapat termasuk membeli rumah, menabung untuk pendidikan anak atau merencanakan pensiun [7].

Perencanaan keuangan pribadi adalah proses pengelolaan uang untuk mencapai kepuasan ekonomi pribadi [8]. Tujuan dan kebutuhan pribadi berubah sejalan dengan tahap kehidupan yang berbeda, oleh karenanya perencanaan keuangan merupakan suatu proses dinamis [9].

Perencanaan keuangan pribadi adalah suatu proses mengatur keuangan individu untuk mencapai kepuasan ekonomi pribadi [8]. Proses perencanaan ini dapat membantu individu dalam mengontrol kondisi keuangannya.

Terdapat beberapa langkah dalam melakukan perencanaan keuangan individu, yang bisa dijelaskan sebagai berikut [8]:

1) Menentukan kondisi keuangan individu saat ini. Setiap individu perlu menentukan kondisi keuangan individu saat ini termasuk penghasilan, pengeluaran, hutang dan tabungan. Hal ini dilakukan dengan membuat neraca keuangan individu yang terdiri dari aktiva lancar dan hutang, serta laporan arus kas yang terdiri dari aliran dana yang dihasilkan dan digunakan selama satu periode.

2) Membuat tujuan keuangan individu. Tujuan keuangan individu dapat bersifat pendek, menengah atau jangka panjang. Tujuan keuangan setiap individu bersifat unik dan tidak selalu sama. Dua orang yang berumur sama pada masa yang sama belum tentu memiliki tujuan keuangan yang sama. Hal ini disebabkan karena adanya perbedaan kemampuan keuangan dan gaya hidup seseorang.

3) Membuat beberapa pilihan untuk memenuhi tujuan keuangan individu. Dalam membuat alternatif pilihan sangat krusial dalam membuat keputusan. Banyak faktor yang mempengaruhi dalam membuat alternatif pilihan, beberapa alternatif pilihan dapat dikategorikan sebagai berikut: melanjutkan situasi yang telah dijalankan, memperluas situasi yang telah berjalan, mengubah situasi yang telah dijalankan, dan membuat situasi yang baru.

4) Evaluasi setiap pilihan yang telah dibuat. Dalam mengevaluasi setiap kemungkinan pilihan, perlu mempertimbangkan kondisi keuangan saat ini, kondisi ekonomi saat ini dan tujuan individu. Setiap keputusan yang diambil mengakibatkan alternatif pilihan yang lain tidak dapat dilakukan. 
Apabila seseorang mengambil keputusan untuk berinvestasi di saham mungkin dalam waktu yang bersamaan tidak dapat berlibur. Opportunity cost merupakan biaya yang dikorbankan pada saat mengambil suatu keputusan.

5) Implementasikan program perencanaan keuangan. Pada tahap implementasi dari program perencanaan keuangan meliputi membuat rencana tindakan yang menentukan jalan untuk mencapai tujuan keuangan.

Tabel 1. Penelitian Sebelumnya

\begin{tabular}{|c|c|c|c|c|}
\hline No. & Nama & Judul & \multicolumn{2}{|c|}{ Hasil } \\
\hline 1. & $\begin{array}{l}\text { Arta M. } \\
\text { Sundjaja, } \\
\text { Jurusan } \\
\text { Sistem } \\
\text { Informasi, } \\
\text { Fakultas Ilmu } \\
\text { Komputer, } \\
\text { Universitas } \\
\text { Bina } \\
\text { Nusantara } \\
{[10]}\end{array}$ & $\begin{array}{l}\text { Perencanaan } \\
\text { Keuangan } \\
\text { untuk } \\
\text { Mencapai } \\
\text { Tujuan } \\
\text { Finansial }\end{array}$ & 2) & $\begin{array}{l}\text { Perencanaan } \\
\text { keuangan pada } \\
\text { mahasiswa } \\
\text { yang } \\
\text { menempuh } \\
\text { studi pada } \\
\text { program studi } \\
\text { ekonomi Islam } \\
\text { di UIN Sunan } \\
\text { Kalijaga dan } \\
\text { Universitas } \\
\text { Islam } \\
\text { Indonesia } \\
\text { secara statistik } \\
\text { tidak memiliki } \\
\text { perbedaan } \\
\text { yang } \\
\text { signifikan. } \\
\text { Secara parsial } \\
\text { hanya } \\
\text { pengetahuan } \\
\text { keuangan yang } \\
\text { secara statistik } \\
\text { signifikan } \\
\text { mempengaruhi } \\
\text { perencanaan } \\
\text { keuangan pada } \\
\text { dua kelompok } \\
\text { mahasiswa. } \\
\text { Secara } \\
\text { simultan, dua } \\
\text { variabel } \\
\text { independen } \\
\text { yaitu } \\
\text { pengetahuan } \\
\text { dan } \\
\text { pengendalian }\end{array}$ \\
\hline
\end{tabular}

\begin{tabular}{|c|c|c|c|c|}
\hline & & & & $\begin{array}{l}\text { bersama-sama } \\
\text { secara } \\
\text { signifikan } \\
\text { mempengaruhi } \\
\text { perencanaan } \\
\text { keuangan. }\end{array}$ \\
\hline 2. & $\begin{array}{l}\text { Sonny } \\
\text { Christian dan } \\
\text { Hendra } \\
\text { Wiyanto } \\
\text { Program Studi } \\
\text { Manajemen } \\
\text { Fakultas } \\
\text { Ekonomi \& } \\
\text { Bisnis } \\
\text { Universitas } \\
\text { Tarumanagara } \\
\text { [11] }\end{array}$ & $\begin{array}{l}\text { Pengaruh } \\
\text { Sikap } \\
\text { Keuangan, } \\
\text { Sosial, dan } \\
\text { Pengetahuan } \\
\text { Keuangan } \\
\text { terhadap } \\
\text { Perencanaan } \\
\text { Keuangan } \\
\text { Pribadi }\end{array}$ & 1) & $\begin{array}{l}\text { Sikap } \\
\text { keuangan } \\
\text { berpengaruh } \\
\text { positif } \\
\text { terhadap } \\
\text { perencanaan } \\
\text { keuangan } \\
\text { pribadi pada } \\
\text { kalangan } \\
\text { milenial yang } \\
\text { telah bekerja } \\
\text { di Jakarta } \\
\text { Barat. } \\
\text { Pengaruh } \\
\text { sosial } \\
\text { berpengaruh } \\
\text { positif } \\
\text { terhadap } \\
\text { perencanaan } \\
\text { keuangan } \\
\text { pribadi pada } \\
\text { kalangan } \\
\text { milenial yang } \\
\text { telah bekerja } \\
\text { di Jakarta } \\
\text { Barat. } \\
\text { Pengetahuan } \\
\text { keuangan } \\
\text { berpengaruh } \\
\text { positif } \\
\text { terhadap } \\
\text { perencanaan } \\
\text { keuangan } \\
\text { pribadi pada } \\
\text { kalangan } \\
\text { milenial yang } \\
\text { telah bekerja } \\
\text { di Jakarta } \\
\text { Barat. }\end{array}$ \\
\hline 3. & $\begin{array}{l}\text { Yuliani, } \\
\text { Rasyid Hs } \\
\text { Umrie, } \\
\text { Samadi W } \\
\text { Bakar } \\
\text { Program Studi } \\
\text { Manajemen, } \\
\text { Fakultas }\end{array}$ & $\begin{array}{l}\text { Perencanaan } \\
\text { Keuangan } \\
\text { Ideal } \\
\text { Rumah } \\
\text { Tangga bagi } \\
\text { Ibu-ibu di } \\
\text { Desa Kota } \\
\text { Daro Ii }\end{array}$ & 1) & $\begin{array}{ll}\text { Ibu-ibu di } & \text { di } \\
\text { Kota Daro } & \text { II } \\
\text { sebagai } & \\
\text { khalayak } & \\
\text { sasaran } & \\
\text { pengabdian } & \\
\text { memiliki } & \\
\text { pengetahuan } & \end{array}$ \\
\hline
\end{tabular}




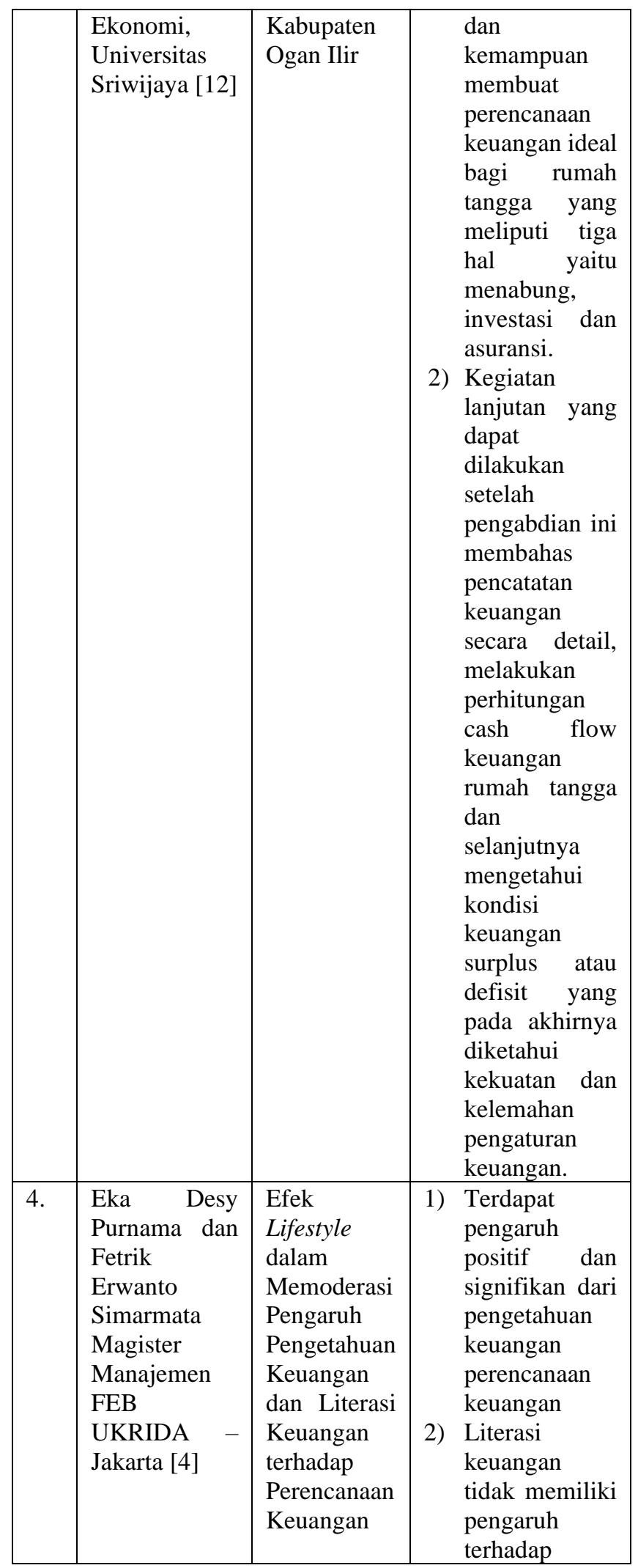

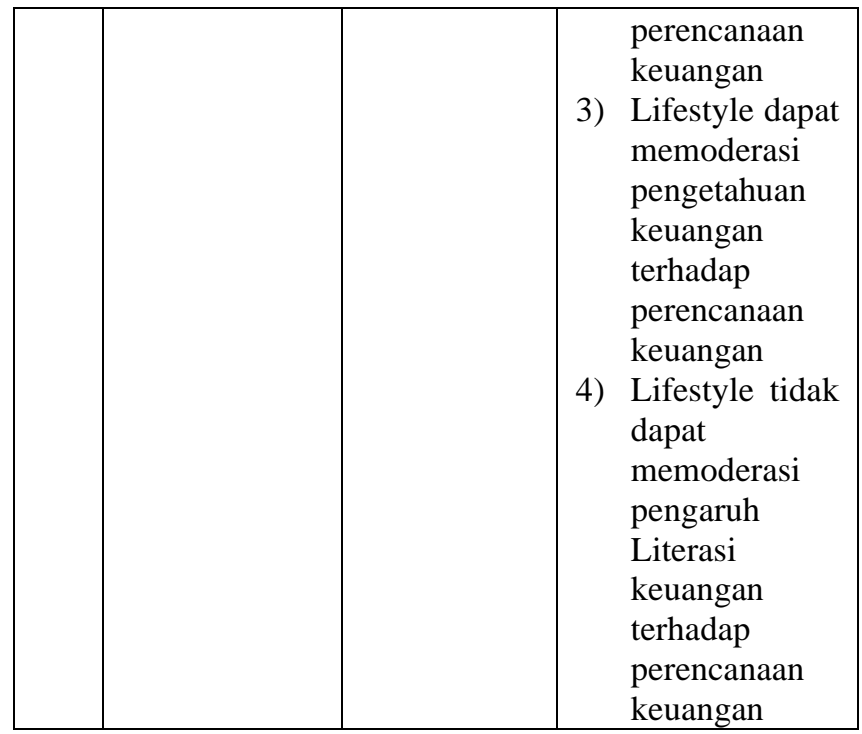

Pengetahuan keuangan yang minim akan menyebabkan seseorang mengalami kesalahan dalam melakukan perencanaan keuangan. Sebaliknya dengan memiliki pengetahuan keuangan yang lebih baik seseorang akan cenderung memiliki perilaku keuangan yang terencana dengan baik, seperti membayar semua tagihan tepat waktu, membukukan pengeluaran setiap bulan, dan mengalokasikan untuk dana darurat [4]. Peningkatan pengetahuan meningkatkan perilaku. Perilaku keuangan atau financial attitude yang dimiliki oleh seseorang akan membantu individu tersebut dalam menentukan sikap dan berperilaku dalam merencanakan keuangan, baik dalam hal pengelolaan keuangan, penganggaran keuangan pribadi, atau terhadap keputusan individu mengenai bentuk investasi yang akan diambil [4].

Dengan melakukan perencanaan keuangan, maka seseorang dapat mencapai tujuan akhir dari perencanaan keuangan yaitu memiliki kebebasan finansial (financial freedom), yang dapat diartikan: bebas dari beban hutang, tersedianya arus penghasilan dari investasi yang telah dilakukannya, serta terproteksi secara finansial dari risiko apapun yang mungkin terjadi [13].

\section{B. Gaya hidup (Lifestyle)}

Gaya hidup dimaknai sebagai pola hidup yang diidentifikasikan oleh bagaimana seseorang menghabiskan seluruh waktu mereka untuk berkativitas, memilih apa yang dianggap prioritas dalam lingkungannya (ketertarikan), dan apa yang dipikirkan tentang diri mereka sendiri dan juga dunia di sekitarnya [14]. Gaya hidup seseorang dapat dicerminkan dari pola konsumsinya. 
Gaya hidup merupakan pola konsumsi yang menggambarkan pilihan seseorang mengenai bagaimana ia menggunakan waktu dan uangnya [15]. Dari definisi tersebut dapat dimaknai bahwa gaya hidup memiliki peranan dalam mempengaruhi konsumsi seseorang dalam pemanfaatan waktu dan uang.

\section{Teori Konsumsi}

Teori dengan hipotesis siklus hidup yang dikemukakan oleh Franco Modigliani menyatakan bahwa pola pengeluaran konsumsi masyarakat didasarkan kepada kenyataan bahwa pola penerimaan dan pola pengeluaran konsumsi seseorang pada umumnya dipengaruhi oleh masa dalam siklus hidupnya. Karena seseorang cenderung memiliki penghasilan/pendapatan yang rendah pada usia muda, tinggi pada usia menengah dan rendah pada usia tua, maka rasio tabungan akan berfluktuasi sejalan dengan perkembangan umur mereka yaitu orang muda akan mempunyai tabungan negative, orang berumur menengah menabung dan membayar kembali pinjaman pada masa muda mereka, dan orang usia tua akan mengambil tabungan yang dibuatnya di masa usia menengah [16]. Usia muda, yakni siswa/i pada masa sekolah, memiliki gaya hidup yang perlu dikelola terutama dalam mempergunakan uang. Literasi keuangan, pendidkan keuangan di keluarga, teman sebaya, dan kontrol diri berpengaruh terhadap manajemen keuangan pribadi mahasiswa [17].

Tujuan dari pengabdian kepada masyarakat ini adalah memberikan pembekalan siswa/i Sekolah Menengah Atas Badan Pendidikan Kristen Penabur Cirebon tentang pengelolaan keuangan di masa pandemi agar kebutuhan hidup tercukupi.

\section{METODE}

Hal yang penting dalam melakukan pengelolaan keuangan pribadi adalah kedisiplinan dalam melakukan kesadaran finansial seseorang, sehingga sikap tersebut dapat menjadi kebiasaan (habits) yang akan membantu individu dan keluarga dalam menciptakan pondasi keuangan yang kokoh dan stabil dalam setiap tahapan kehidupan.

Oleh karena itu, demi terciptanya pondasi keuangan kokoh dan stabil yang dipersiapkan sejak dini di tengah situasi pandemi, maka kegiatan ini bertemakan "Pengelolaan Keuangan Pribadi Bagi Siswa Siswi SMA Badan Pendidikan Kristen Penabur Cirebon di Masa Pandemi"

Adapun kegiatan pengabdian pada masyarakat ini dilakukan oleh dosen-dosen FEB UKRIDA kepada siswa siswi SMA Badan Pendidikan Kristen Penabur Cirebon yang berlokasi di J1. DR. Cipto Mangunkusumo No.24, Pekiringan, Kec. Kesambi, Kota Cirebon, Jawa Barat 45131. Dari segi kepesertaan bisa dirinci sebagai berikut: Dosen FEB Ukrida 4 orang, mahasiswa Ukrida 5 orang, Siswa siswi SMA Badan Pendidikan Kristen Penabur Cirebon dan perwakilan guru sebanyak 82 orang. Berikut adalah tahapan mulai dari persiapan sampai tahap pelaksanaan. Kegiatan ini dilaksanakan pada hari Rabu, 16 Juni 2021 secara virtual. Adapun proses pelaksanaan pengabdian masyarakat digambarkan sebagai berikut:

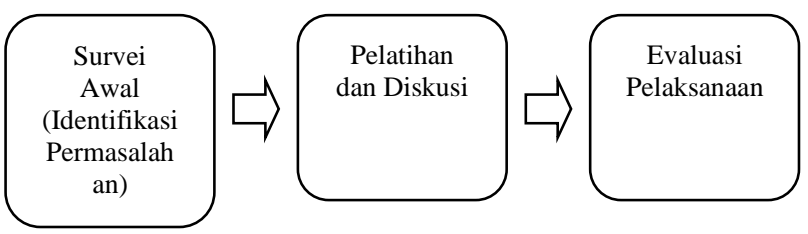

Gambar 1. Proses Pelaksanaan Pengabdian Masyarakat

Dapat dilihat pada gambar 1, bahwa tahap pelaksanaan pengabdian pada masyarakat ini dimulai dengan adanya survei awal dengan mengidentifikasi adanya permasalahan pada siswa-siswi calon peserta kegiatan ini. Siswa siswi SMA Badan Pendidikan Kristen Penabur Cirebon memiliki gaya hidup seperti layaknya generasi muda yang lain, dalam membedakan antara kebutuhan dan keinginan. Kondisi pandemi yang tengah berlangsung menyebabkan mereka sulit untuk mengatur pola konsumsinya. Pemahaman ini melatarbelakangi kebutuhan edukasi perencanaan dan pengelolaan keuangan pribadi untuk siswa siswi SMA Badan Pendidikan Kristen Penabur Cirebon di Masa Pandemi.

Adanya kebutuhan edukasi tentang pengelolaan keuangan pribadi bagi siswa siswi SMA Badan Pendidikan Kristen Penabur Cirebon di Masa Pandemi membuat para dosen FEB Ukrida tergerak untuk memberikan seminar dan diskusi seputar topik pengelolaan keuangan, khususnya untuk pribadi. Seminar dan diskusi dilakukan melalui media zoom, dan diskusi lanjutan dimungkinkan melalui WA grup. Setelah selesai pelaksanaan, maka dilakukan evaluasi bersama panitia pelaksana kegiatan pengabdian masyarakat.

\section{IV.Pembahasan}

Kegiatan pengabdian kepada masyarakat ini diikuti oleh 91 peserta yang terdiri dari siswa siswi, dan perwakilan guru dari SMAK BPK Penabur Cirebon, serta mahasiswa panitia dan tim dosen pengabdian masyarakat dari Ukrida. Kegiatan ini dilakukan dalam bentuk seminar online melalui media zoom dengan pemateri adalah Dr. Diana Frederica, SE., MAk., $\mathrm{CFP}^{\circledR}$ dan tim dosen Fakultas Ekonomi dan 
Bisnis Ukrida. Beliau adalah salah satu dosen FEB Ukrida yang telah memiliki sertifikasi Perencana Keuangan (Certified Financial Planning). Seminar online ini dipandu oleh Gabbrille Olivia salah satu mahasiswa FEB Ukrida. Dosen FEB Ukrida lainnya yang tergabung dalam kegiatan ini juga sudah tersertifikasi sebagai perencana keuangan, dimana kebutuhan masyarakat akan edukasi ini disesuaikan dengan kompetensi narasumber dalam hal ini dosen-dosen FEB Ukrida. Kegiatan ini dilaksanakan pada hari Rabu, 16 Juni 2021.

Pemaparan materi diawali dengan menggali pola pikir siswa-siswi dengan pertanyaan: Apa yang Anda pikirkan ketika mendengar kalimat financial goals? Ada yang menjawab, ingin memiliki financial freedom. Lalu diulaslah tentang financial freedom. Pemaparan materi diawali dengan sebuah ilustrasi mengenai efek diderot yang muncul ketika kita bersosialisasi. Adanya keinginan membeli barang akibat lingkungan sekitar, yang sebenarnya bukan merupakan kebutuhan kita. Hal ini terjadi terus menerus hingga mempengaruhi kondisi keuangan. Dalam kondisi pandemi saat ini, dimana ruang gerak menjadi terbatas, kegiatan beralih kepada media sosial dan e-commerce. Banyak tawaran menarik yang kemudian pengeluaran menjadi tidak terkontrol. Peserta diajak untuk membedakan antara mana yang memang menjadi sebuah kebutuhan harus dibeli, dan mana yang hanya merupakan keinginan saja atau efek dari bersosialisasi. Financial freedom dapat tercapai apabila kita memiliki financial planning yang baik khususnya cash flow management.

Agar tercapainya financial freedom terdapat delapan langkah yang perlu dilakukan, yaitu (1) mencatat semua pengeluaran, dengan pencatatan maka kita bisa menganalisis pengeluaran mana yang terlalu tinggi dan pengeluaran mana yang bisa diminimalkan berdasarkan prioritas kebutuhan; (2) menghilangkan pengeluaran yang tidak perlu, cek apakah pengeluaran tersebut merupakan kebutuhan mendesak atau hanya sebuah keinginan; (3) pelajari skill mencari penghasilan, melalui skill yang dimiliki maka dapat menambah peluang penghasilan; (4) menciptakan sumber income baru, karena tidak semua area pengahsilan dapat bertahan, sehingga ketika satu area sedang menurun, maka diperoleh dari sisi area yang lainnya; (5) sisihkan income, kemudian belanjakan sisanya. Beberapa orang berperilaku membelanjakan uang untuk keperluannya (yang bisa jadi hanya sebuah keinginan), kemudian menabung menginvetasikan sisanya. Hal ini merupakan langkah yang kurang tepat, karena penghasilan akan cenderung habis. (6) menginvestasikan penghasilan secara bijaksana. Berinvestasi tentunya harus memiliki strategi, menganalisis risiko, dan melihat profile risiko diri sendiri. (7) menginvestasikan ulang hasilnya. Ketika kita investasikan hasil investasi, maka akan berlipatkali ganda. (8) hidup dengan passive income. Memilih bisnis yang mendatangkan passive income, cenderung memberikan kita kebebasan dalam beraktivitas. Setelah beberapa langkah awal dilakukan, maka proses menuju financial freedom diharapkan akan terealisasi.

Peserta cukup antusias dan mulai membahas lebih dalam tentang cash flow management. Terdapat beberapa tips cara mengatur keuangan, yaitu (1) jangan pernah bergantung pada satu sumber penghasilan dan mulailah berivestasi, (2) jangan membeli barang yang sebenarnya tidak diperlukan, (3) jangan menabung dari sisa belanja tetapi belanja dari sisa menabung, (4) hindari hutang, (5) jangan meletakkan semua telur dalam satu keranjang tetapi lakukan diversifikasi, serta (6) buatlah anggaran. Anggaran dapat menjadi "rem" bagi kita ketika pos-pos tertentu sudah mendekati batas yang dianggarkan. Melalui anggaran, kita dapat memprediksi pengeluaran ke depan, dan masih banyak lagi fungsi dari anggaran.

Terdapat peserta yang bertanya, bagaimana cara menabung, karena seringkali penghasilan hanya pas untuk kebutuhan saja. Hanya terdapat dua pilihan, yaitu dengan cara menambah penghasilan atau mengurangi pengeluaran. Apabila pengeluaran tetap, maka tambahlah penghasilan. Namun apabila penghasilan sulit untuk ditambah, maka kurangilah pengeluaran. Di samping topik-topik tersebut, juga dibahas tentang manajemen hutang. Penggunaan hutang hendaknya untuk hutang produktif, bukan hutang konsumtif. Contoh hutang produktif adalah hutang untuk menjalankan usaha. Hutang produktif adalah hutang yang digunakan untuk kegiatan yang menghasilkan uang. Sehingga penghasilan akan berkalilipat ganda. Sementara itu, hutang konsumtif adalah hutang yang digunakan untuk kegiatan konsumtif, tidak untuk menghasilkan uang.

Pertanyaan lainnya dari peserta adalah, bagaimana membedakan antara kebutuhan dan keinginan. Ketika barang/jasa tersebut tidak kita beli, tidak ada dampak "kerugian" yang kita rasakan, maka sebenarnya itu hanya sebuah keinginan. Berbeda halnya ketika kita tidak membeli barang tersebut, ada dampak "kerugian" yang kita rasakan, maka itu adalah sebuah kebutuhan yang harus dipenuhi.

Diahkir kegiatan ini, dilakukan dokumentasi dan pengisian form evaluasi. Penyelenggaraan ini diharapkan dapat memberikan wawasan tentang bagaimana cara mengelola keuangan bagi peserta di era pandemi saat ini, mampu membedakan keinginan dan kebutuhan, serta manajemen hutang yang tepat. 


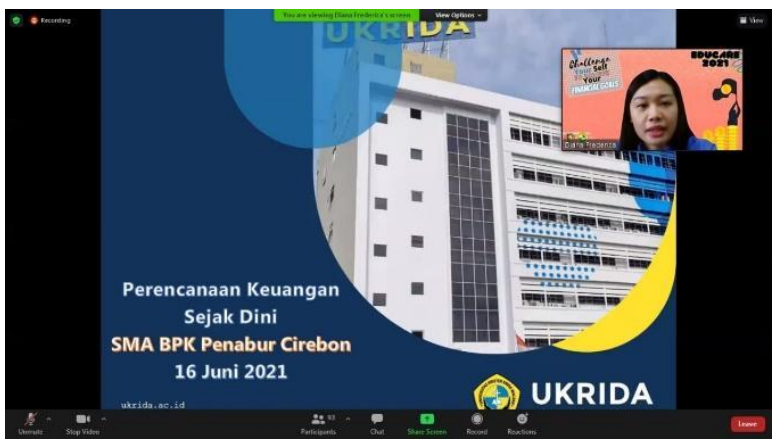

Gambar 2. Kegiatan Pelatihan

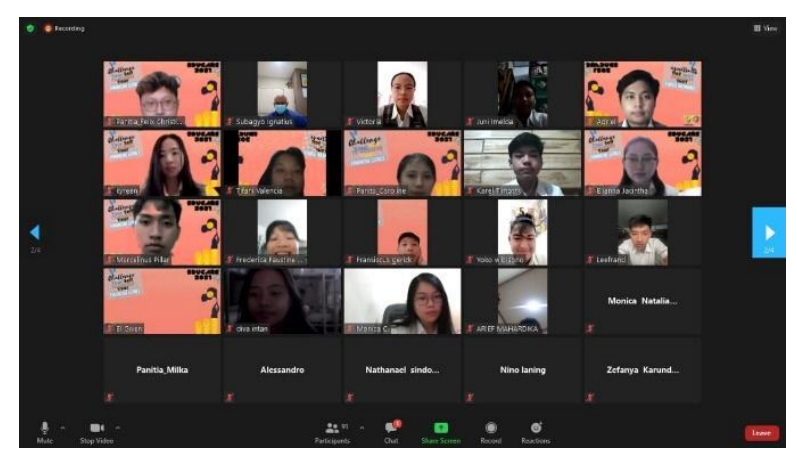

Gambar 3. Foto Bersama

\section{Kesimpulan}

Kegiatan pengabdian kepada masyarakat ini telah berhasil dilaksanakan dengan beberapa pencapaian berikut ini: (1) Terlaksana program pelatihan pengelolaan keuangan bagi siswa-siswi SMAK BPK Penabur Cirebon; (2) Terlaksana ruang diskusi tanya jawab mengenai pengelolaan keuangan di era pandemi; (3) Para peserta telah memahami perbedaan antara kebutuhan dan keinginan yang berkaitan dengan pengeluaran uang. Kegiatan ini memberikan implikasi bagi perkembangan ilmu pengetahuan di bidang keuangan khususnya pengelolaan keuangan di usia muda, bagaimana management cash flow, dan pemahaman manajemen hutang. Kegiatan ini dapat dijadikan masukan dan evaluasi untuk pendidikan khususnya pada mata kuliah manajemen keuangan.

Keberlanjutan kegiatan pengabdian kepada masyarakat dalam rangka literasi keuangan tentang pengelolaan keuangan pribadi dapat dilakukan secara berkala kepada para siswa-siswi. Pendampingan pengelolaan dan pencatatan keuangan dapat dilakukan sampai menjadi gaya hidup, sehingga penggunaan keuangan akan terjaga sesuai kebutuhan, bukan untuk keinginan semata.

Refleksi dari kegiatan ini dilakukan melalui pengisian kuesioner pada google form. Para siswa menyatakan kegiatan ini sangat bermanfaat bagi mereka dan sangat antusias untuk dilakukan kembali dengan materi yang lebih dalam.

\section{UCAPAN TERIMA KASIH}

Ucapan terima kasih ditujukan kepada Fakultas Ekonomi dan Bisnis UKRIDA dan Yayasan serta Kepala Sekolah SMA Badan Pendidikan Kristen Penabur yang turut terlibat secara langsung atau tidak langsung dalam mensukseskan kegiatan ini.

\section{DAFTAR PUSTAKA}

https://smeru.or.id/id/content/ringkasan-eksekutif-dampaksosial- ekonomi-covid-19-terhadap-rumah-tangga-danrekomendasi), diunduh, 10.52, Tanggal 6 Agustus 2021

[2 https://databoks.katadata.co.id/datapublish/2020/06/26/survei

] -smrc-kondisi-ekonomi-keluarga-lebih-buruk-setelahpandemi-covid-19, diunduh, 14.30, Tanggal 8 Agustus 2021

[3 https://www.modalrakyat.id/blog/pentingnya-perencanaan-

] keuangan-pribadi, diunduh, 14.30, Tanggal 8 Agustus 2021

[4 Eka Desy Purnama dan Fetrik Erwanto Simarmata, Efek

] Lifestyle Dalam Memoderasi Pengaruh Pengetahuan Keuangan dan Literasi Keuangan Terhadap Perencanaan Keuangan, Jurnal Inovasi Penelitian, Vol.1 No.8, Januari 2021.

[5 https://www.cnnindonesia.com/gaya-

] hidup/20180418215055-282-291845/alasan-generasimilenial-lebih-konsumtif, diunduh 22.08, Tanggal 7 Agustus 2021

[6 Mankiw, Gregory, Principles of Economics, 8th Edition, Cengage learning, 2018.

[7 Budisantoso, Indrasto dan Gunanto, Cara Gampang Mengelola

] Keuangan Pribadi dan keluarga, Jakarta: PT. Gramedia Pustaka Utama, 2010.

[8 Jack R. K., Les R. D., and Robert J. Personal finance, New

] York: McGraw-Hill. 2004.

[9 Gitman, Lawrence and Joehnk. Principal of Managerial

] Finance. 11th edition. United States; Pearson. 2005.

[1 Sundjaja, A.M. Perencanaan Keuangan untuk Mencapai

0] Tujuan Finansial, ComTech Vol.1 No.1, Hal 183-191. 2010.

[1 Christian, S dan Wiyanto, H. Pengaruh Sikap Keuangan,

1] Sosial, dan Pengetahuan Keuangan terhadap Perencanaan Keuangan Pribadi, Jurnal Manajerial dan Kewirausahaan, Volume II No. 3. Hal: 820-827. 2020.

[1 Yuliani, Rasyid Hs Umrie, Samadi W Bakar, Perencanaan

2] Keuangan Ideal Rumah Tangga Bagi Ibu-Ibu di Desa Kota Daro Ii Kabupaten Ogan Ilir, Wikrama Parahita: Jurnal Pengabdian Masyarakat JPM Wikrama Parahita, Volume 4 No.2. 2020 .

[1 Purnama, E.D, Frederica, D, Adirinekso, G, Iskandar, D.

3] Perencanaan Keuangan Dana Pensiun Melalui Metode Time Value of Money dengan Menggunakan Kalkulator Finansial, Jurnal Abdikarya Sakti, Vol. 1 No. 1, Hal : 47-62, 2021.

[1 Setiadi, Nugroho J. Perilaku Konsumen (Konsep dan

4] Implikasi untuk Strategi dan Penelitian Pemasaran). Jakarta: Prenada Media. 2003.

[1 Sumarwan, Ujang. Perilaku Konsumen (Teori dan

5] Penerapannya dalam Pemasaran). Edisi ke-2. Bogor: Ghalia Indonesia. 2014. 
[1 Kusuma, B. Analisis Faktor-Faktor Yang Mempengaruhi

6] Konsumsi Masyarakat Di Indonesia (Tahun 1988-2005). Yogyakarta: FE Universitas Islam Indonesia. 2008.

[1 Rosa, I dan Listiadi, A, Pengaruh Literasi Keuangan,

7] Pendidikan Keuangan di Keluarga, Teman Sebaya, dan

Kontrol Diri terhadap Manajemen Keuangan Pribadi, Jurnal Manajemen, Volume 12 No.2, 2020. 